\title{
Tort Law: Defects of the Comparative Negligence Standard
}

\author{
Dagobert L. Brito and Peter R. Hartley
}

I

NDIVIDUALS and corporations continually engage in activities that could result in accidents. How much care ought they to take, and how might they be encouraged to take it?

Tort law allocates risk between parties who are not in a contractual relationship, or where a dispute is not covered by a contract. The apportionment of liability in particular tort cases affects incentives to take care in similar situations in the future. The liability rules that evolved over centuries of litigation took these incentive effects into account. The result was a system that encouraged efficient expenditures on care. At the same time, clearly defined legal standards of care, together with strong incentives to meet those standards, discouraged unnecessary litigation.

Within the last century, the 'all or nothing' rule of negligence with a defence of contributory negligence has been replaced in most jurisdictions in the Englishspeaking world by 'comparative negligence' rules that apportion damages in accordance with fault. In the first instance, and in most jurisdictions, the replacement of contributory by comparative negligence was effected through legislation. The change was not defended on the grounds that it was likely to encourage more efficient care. Rather, the change reflected a view that the compensation of injured parties in itself was an appropriate goal of the legal system. Yet the change to comparative negligence has probably resulted in less efficient care, increased litigation and more expensive trials. The increase in litigation may have been greater in the United States because contingency fees lower the expected compensation required to make litigation worthwhile. If so, moves to introduce contingency fees in some Australian jurisdictions may further increase the amount of litigation in Australia.

\section{Efficiency of the Common Law Rules of Liability}

There are several common law rules of liability. This article focuses on comparative negligence and the rule it largely replaced, contributory negligence. Neverthe-

\footnotetext{
'England, Australia and New Zealand refer to apportionment rules as 'contributory negligence'. We follow United States practice and use 'comparative negligence' for the new rules and retain 'contributory negligence' for the common law rule.
}

Dagobert Brito is the Peterkin Professor of Political Economy at Rice University. Peter Hartley is Executive Director of the Tasman Institute, on leave from Rice University. 
less, in some situations, other liability rules are likely to be needed to encourage efficient behaviour.

Under a strict liability regime, the injurer is always liable for all damages suffered by a victim. Under a negligence regime, the injurer is liable only if it can be shown that he took less than a 'reasonable' amount of care.

Strict liability and negligence are likely to have different consequences for efficiency when participation in an activity affects the expected accident losses. Since the value of engaging in an activity is likely to include significant factors that are not objectively verifiable, it is usually beyond the purview of the court. However, a negligence regime will not provide incentives for individuals to control their participation in an activity when participation is excluded from the negligence standard. By contrast, under a strict liability regime, the potential injurer will always bear the total costs of any accident, and will therefore have appropriate incentives to trade off the benefits from participating in an activity against the possible accident losses.

Strict liability, and, to a lesser extent, negligence, are unlikely to provide appropriate incentives to take care when a potential victim can also take reasonable precautions to reduce expected accident losses. If victims can recover all, or most, of the damages resulting from accidents, they will have little incentive to take care. This problem was recognised under the common law negligence regime by providing a defence of contributory negligence. This defence absolves the injurer from liability whenever there was any negligence on the part of the victim. In effect, there is a standard of care for potential victims as well as potential injurers. The defence of contributory negligence is generally held ${ }^{3}$ to have originated in 1809 with the English case of Butterfield $v$ Forrester, where a rider was injured after his horse ran into an obstruction, apparently discernible at a distance of 100 yards, which had been placed on a highway by the defendant so that he could repair his house. In judgment on the case, Judge Bayley said: 'If he had used ordinary care he must have seen the obstruction; so that the accident appeared to happen entirely from his own fault'; while Lord Ellenborough commented: 'One person being in fault will not dispense with another's using ordinary care for himself'.

Toward the end of the 19th century, contributory negligence was criticised for being unfair to victims. In particular, when both parties had met their respective standards of care, or both were deemed negligent, the victim could not recover any compensation from the defendant. Perhaps as a result of these criticisms, various qualifications were introduced to the defence of contributory negligence. The most significant of these became known in the US as the 'last clear chance' doctrine. It

\footnotetext{
2

2 Exceptions arise if injurers are rarely negligent, as happens under the most efficient negligence rules, or if injurers and victims are in a contractual relationship where an injurer can compensate a victim to take appropriate care.

3

Rogers (1994:175) notes the idea is older. He cites Sanders $v$ Spencer, 3 Dyer 266b. (1567) where 'the strict liability of an innkeeper for the safe-keeping of his guest's goods was negatived if the goods were stolen by the guest's own fault'.

${ }^{4} 11$ Fasts Reports 59, 103 Eng. Rep 926 (1809).
} 
originated in England as the 'rule of last opportunity' in Davies ${ }_{6}$ Mann, which was approved by the House of Lords in Radley $v$ L\&N.W. Ry. In Fuller $v$ Illinois Central R.R. Judge McLain summarised the qualification as follows: 'The contributory negligence of the party injured will not defeat the action if it is shown that the defendant might by the exercise of reasonable care and prudence have avoided the consequence of the injured party's negligence'. The High Court of Australia discussed a number of qualifications to the defence of contributory negligence in Alford $v$ Magee. The High Court cited Davies $v$ Mann as the source for the qualification where the defendant's negligent conduct was substantially later in point of time than the plaintiff's. Another qualification was a situation where the defendant, but not the plaintiff, had 'a real opportunity, of which a reasonable man would have availed himself, of avoiding the mischief'.

However, the doctrine of last clear chance has efficiency implications. It is relevant only in a dynamic setting where decisions to take care are made sequentially. In the case of negligence with a defence of contributory negligence, both injurers and victims can take care to avoid an accident. If victims choose care first, an injurer will have no incentive to take care whenever he knows he is facing a victim who has not met the standard. By leaving the injurer liable, the doctrine of last clear chance continues to provide the injurer with an incentive to avoid an accident. In doing so, however, the doctrine may also provide inappropriate incentives for a potential victim. Suppose a potential victim knows that, if an accident occurs, it will always be in a situation where the injurer will be found to have a 'last clear chance' to avoid the accident. The victim then has no incentive to avoid the accident.

\section{Comparative Negligence}

The comparative negligence rule allocates damages according to the relative negligence of the parties. It originated in its current form in the early 1900 s, when the US Congress introduced provisions for apportionment of damages in several federal safety and employment statutes. There was, however, fleeting judicial acknowledgment of a weak form of comparative negligence in Illinois in 1858. In Galena \& Chicago R.R. v Jacobs, a case where a four-year-old boy was run over by an engine and the defence was substantially the contributory negligence of the child and his parents, the court noted that 'as in all like cases, the degrees of negligence must be measured and considered, and wherever it shall appear that the plaintiff's negligence is comparatively slight, and that of the defendant gross, he shall not be deprived of his action'.

\footnotetext{
In Davies V Mann 10M. \& W. 546 (1842) the defendant was found liable for colliding with the plaintiff's donkey, even though the donkey had been set loose to graze the verges of the highway. 6

App. Cas. 759 (1876)

100 Miss. 705, 716-18, 56 So. 783, 785-6 (1911).

8

(1951-2) 85 C.L.R. 437.

${ }^{9} 20$ Ill. $478,496-7$ (1858).
} 
In the 1970 s and 1980 s, most states in the US either enacted comparative negligence statutes or adopted the principle judicially. California adopted the principle in 1975 in Liv Yellow Cab Co. of California. The court acknowledged practical considerations that militated against the adoption of comparative negligence. It noted that the adjudication of disputes under such a rule is 'a matter of perplexity' and a 'complex task'. Since more material facts need to be established in order to apportion damages, the costs of each litigation will be higher under a comparative negligence regime. The court nevertheless decided that 'the inherent difficulties were not insurmountable'. At the time of the California decision, 25 states in the US had enacted statutes to replace contributory with comparative negligence. As of 1986, all but six states and the District of Columbia had switched to a comparative negligence standard.

In England, the Law Reform (Contributory Negligence) Act 1945 provided for apportionment of damages 'wherever both parties have been negligent and both have contributed to the damage'." Trindade and Cane (1985:424) report that, in Australia, the apportionment of damages was introduced in a series of statutes in South Australia (1936), Western Australia (1947), Queensland (1952), Tasmania (1954), the Australian Capital Territory (1955), the Northern Territory (1956), Victoria (1958), and New South Wales (1965). In New Zealand, apportionment of damages was introduced in the Contributory Negligence Act (1947).

\section{Comparing the Contributory and Comparative Negligence Regimes}

When the California court was choosing between different negligence regimes, the effects of each regime on incentives to take care were not considered salient. Until recently, it had been widely accepted that, although contributory negligence might be considered 'unfair', it nevertheless provided appropriate incentives for injurers and victims to take care.

Legal scholars have recently challenged this view, however, and there is now considerable controversy about the efficiency of contributory and comparative negligence. Rubinfeld (1987) argues that a linear rule for allocating damages must be able to do at least as well as the contributory negligence rule in encouraging care, since the policy-maker has more free parameters. Contributory negligence can be viewed as a special case of comparative negligence where the 'sharing rule' takes on a discrete all-or-nothing character.

\footnotetext{
${ }^{10} 13$ Cal. 3d 804, 532 P.2d 1226, 119 Cal. Rptr. 858 (1975).

${ }^{11}$ Rogers (1994:176), who also notes that, "It is still open to the court to conclude that the fault of only one party was the sole effective cause of loss but all the refinements of "last opportunity" have gone'.

12

The English, Australian and New Zealand legislation uses 'contributory negligence' to refer to 'comparative negligence'.

13

In Brito and Hartley (1995a), we show Rubinfeld's numerical calculations are in error. Nevertheless, his argument that a comparative negligence regime has more 'free parameters' is valid. As we shall see, however, it is not necessarily decisive.
} 
Rubinfeld envisages a situation where both injurers and victims can take actions to reduce expected accident losses and, as is likely in practice, individuals differ in their cost of care. These costs will often involve factors that are difficult to measure or verify, and therefore will be known only to the individuals concerned. When choosing a prudent amount of care, a potential injurer or victim will have to base his decision on the range of care likely to be taken by members of the other group. Similarly, when deciding whether individuals have taken adequate care, the courts cannot base their decision on the unknown individual costs for avoiding accidents. Rather, the appropriate standards of care will depend on the accident avoidance costs of the average (or 'reasonable') person in each party's situation.

The efficient amount of care for an injurer or victim can be found by minimising the expected cost of accidents plus the cost of care. An injurer (or victim) should be required to take care only up to the point where the marginal costs of that additional care equal the reductions in expected accident losses assuming all other individuals take the efficient amount of care.

In response to a liability rule, potential injurers or victims would choose care to minimise their respective expected damages plus their cost of care. In each case, when choosing care, they would take the equilibrium care of other individuals as given independently of their own choices.

An interesting special case is where victims differ in their costs of care but injurers do not. There are many examples of a single business serving customers who differ in their ability to take care. Furthermore, even when there are several firms in an industry, the firms are likely to have similar technologies and costs for controlling risks. We examine this special case, and also the symmetric case where only injurers differ in their costs of care, in Brito and Hartley (1995a). We show that, if efficient injurer and victim care can be determined unambiguously, and involves positive care by some individuals in both parties, then contributory negligence rules that achieve the efficient outcome can be found. ${ }^{14}$ Since these negligence rules are efficient, they cannot be improved on by a comparative negligence rule. Further, any comparative negligence rule that results in a different amount of care will not do as well. The additional degrees of freedom to affect incentives to take care that are, in principle, available under comparative negligence turn out in these cases to be useless.

When the injurers are homogeneous and the victims are heterogeneous, the best contributory negligence rule takes the efficient amount of care for injurers as the legal standard of an injurer, and sets a legal standard of zero care for the victims. Since the legal standard of victims is zero, the best contributory negligence rule in this case is equivalent to a negligence rule without a defence of contributory negligence. All injurers will find it in their interest to meet the legal standard since it equates the marginal costs and expected marginal benefits of taking care. Victims then expect to bear full damages and thus also will choose the efficient amount of

\footnotetext{
${ }^{14}$ When the injurers are heterogeneous, and the victims are homogeneous in their costs of care, we also need to assume care by the two parties is complementary.
} 
care and an efficient level of participation in the activity. Even though victims can affect the accident probability, a negligence rule gives them appropriate incentives to take care. ${ }^{15}$ If the injurers are heterogeneous, and the victims are homogeneous, the best contributory negligence rule takes the efficient amount of care for victims as the legal standard of a victim, and sets a legal standard for injurers that no injurer will achieve.

When the victims are heterogeneous and there is just one potential injurer, the injurer should be required to take care up to the point where the marginal cost of care equals the reduction in expected losses for possible accidents involving any member of the population of potential victims. The marginal benefits of care measured in this way generally will not equal the marginal value of additional care given the actual care exercised by the victim in a particular accident. We can define a 'representative' or 'reasonably careful' potential victim as one taking care that would make injurer care as productive as it would be across the population of all victims.

In Brito and Hartley (1995a), we examine the relationship between the representative victim so defined and the victim whose cost of taking care equals the average cost for the population of all victims. For example, when care by victims is a perfect substitute, or a perfect complement, for care by the injurer, we show that the reasonably careful victim is one whose cost of care is less than or equal to the cost of care of the average victim. When the accident probability depends on the product of the care levels, we show that the reasonably careful victim is the individual whose expenditure on care equals the per capita expenditure by the group of victims as a whole.

The mathematical model thus allows us to distinguish the average member of the group from the member whose care would make injurer care as productive as it is on average. In practice, judges and juries are unlikely to have the data necessary to make such fine distinctions. However, the model does provide support for a traditional common law definition (Posner, 1992:167) of the reasonably prudent person as average. This point can be illustrated by the following cases.

In McCarty $v$ Pheasant Run, Inc. the plaintiff was a woman who was attacked in her hotel room by an intruder who entered by way of an unlocked sliding glass door. Posner argues, 'A notice in every room to lock all doors would be cheap, but most people know better than to leave the door to a hotel room unlocked when they leave the room ...'17 (emphasis added). A lock to foil a Houdini ... would

\footnotetext{
${ }^{15}$ Similarly, in the case where both injurers and victims are homogeneous, the efficient amount of care for injurers is taken as their legal standard of care, while the legal standard for victims is set at zero. Again, injurers will find it in their interest to meet the legal standard, and since victims then cannot recover damages they will also choose an efficient amount of care.

16

In this case, the rule will also be efficient if participation by injurers alone affects the accident probability.

17

826 F.2d 1554, 1557.
} 
have thus done her no good ... ${ }^{18}$ if she failed to lock the door. This decision can be contrasted with O'Brien v Muskin Corp. ${ }^{19}$ where a 23-year-old man dived (possibly from the roof of an eight-foot garage) into an above-ground swimming pool that was four feet deep. This case was reversed and remanded with the jury asked to evaluate 'whether, because of the dimensions of the pool and the slipperiness of the bottom, the risks of injury so out weighted the utility of the product as to constitute a defect'. However, if the average adult knows that diving into a four-feet deep above-ground swimming pool is not prudent behaviour, then it is not efficient to impose on the manufacturer the duty to guard against such behaviour. Evaluating what one can expect of the average adult is easier than evaluating the social utility of a swimming pool. In Pomer $v$ Schoolman ${ }^{20}$ the plaintiff was a truck driver who walked into a corn head (a mechanical device for picking corn) and lost his legs. The corn head is an obvious hazard and the defendant 'had no reason to think that Pomer — that any adult — would approach within range of an operating corn head'.

In Levi $v$ Southwest Louisiana Electric Membership Cooperative ${ }^{22}$ an oil-field roustabout-pumper raised the mast of a paraffin removal truck into a 14,400 -volt power line that was 25.7 feet in the air. The Supreme Court of Louisiana reversed a judgment in favour of the defendant on the grounds that the power company had a duty to guard against the plaintiff's negligence. However, if the average oil-field roustabout-pumper is aware that 14,400-volt power lines are dangerous, and average prudence would suggest looking up before raising the mast of a truck, then it is not efficient to impose on the power company the duty to guard against such behaviour.

In another paper (Brito \& Hartley, 1995b) we examine the situation where injurers and victims both differ in their costs of care. In this case, in general no liability or negligence regime is able to induce all parties to take efficient amounts of care. Nevertheless, a rule of negligence with a defence of contributory negligence can attain expected costs that are very close to the efficient levels. For example, for a category of accidents where the expected damages are of the order of $\$ 1 \mathrm{~m}$, the excess costs under the best contributory negligence rule ranged from a little over $\$ 1,000$ to a little over $\$ 9,000$. Expressed as a percentage of the expected costs under efficient care, the excess costs under the best contributory negligence rule ranged from less than 0.5 per cent to slightly above 7.25 per cent with an average of about 2.5 per cent.

The size of the excess costs under the best contributory negligence rules depended mainly on the costs of injurer care. In particular, the best contributory negligence rule performs relatively better when injurers have lower average costs of care. Contributory negligence also performs relatively better (in percentage terms)

\footnotetext{
${ }^{18} 826$ F.2d 1554, 1560.

19

94 NJ. 169, 463 A.2d 298.

${ }^{20} 875$ F.2d 1262.

21875 F.2d 1262, 1267.

22

542 So.2d 1081.
} 
when care is complementary. Both these results are explained by the fact that, in all our examples, care taken under the best contributory negligence rule deviated from the efficient levels by inducing injurers to supply excessive care on average. This is less costly when injurer costs are lower, since the efficient solution would in that case require relatively higher care from injurers. It is also less costly when care is complementary because, again, the efficient solution would require relatively high care from both parties regardless of their relative costs.

When costs are uniformly distributed, more than 99.5 per cent of injurers meet the legal standard under the best contributory negligence rules. Even when the distribution of costs is skewed toward low values (so it is best to set a high standard to encourage the many low-cost injurers to take substantial care), more than 96 per cent of injurers meet the standard. Injurers have a strong incentive to meet the standard, even when it is high, since by doing so they are exempt from liability.

For all distributions and parameter values, victims choose close to the efficient amounts of care under the best contributory negligence rules. If all injurers met their legal standard, victims would effectively be in an assumption-of-risk regime where they could not expect to recover damages. As a result, they would have an incentive to trade-off optimally the costs and benefits of care and thus choose the efficient amount of care.

We also attempted to find the best comparative negligence rules when care affects the probability of an accident in a simple way. We did not find, as the California court claimed, that the 'assigning of a specific percentage factor to the amount of negligence attributable to a particular party (is) . . . in theory a matter of little difficulty'. On the contrary, it is extremely difficult to find a theoretically ideal liability sharing rule. It is very difficult, if not impossible, to predict the effect of most sharing rules on equilibrium care. We were able to do so only where the costs of care for both injurers and victims were uniformly distributed and the sharing rules were of a special, and quite complicated, form. In particular, we could not determine equilibrium care under simple linear sharing rules, even for uniform distributions of the costs of care.

The special sharing rule where we could determine likely behaviour, and thus decide on a best feasible set of legal standards, would be extremely difficult to implement. However, simple rules are likely to have unpredictable effects on behav-

\footnotetext{
23

This is shown formally in Brito and Hartley (1995b) for the uniform distribution case. For other distributions, the victims may choose care that is only approximately efficient, even if all injurers meet their legal standard, because the average efficient care of injurers need not equal the care under the legal standard.

24

When almost all injurers meet their legal standard, victims also have close to the right incentives to choose the appropriate level of participation in the potentially dangerous activity. Hence, the best contributory negligence rule will also perform well if the accident probability is sensitive to victim, but not injurer, participation. Similarly, with almost all injurers meeting their legal standard, victims will usually have appropriate incentives if they choose care after injurers. The best contributory negligence rule will not give appropriate incentives to injurers to take care, however, if injurers choose care knowing the care that victims have taken.
} 
iour. There is little rational basis, therefore, for choosing a sharing rule in a comparative negligence regime. Standards of care sufficient to absolve one from a given share of damages are likely to vary greatly from one trial to the next. Tort cases based on comparative negligence rules may become little more than gambles. Victims may be encouraged to 'try their luck' even when their case appears weak.

The choice of care by injurers and victims under the two regimes will also tend to produce more litigation in a comparative negligence regime. Almost all injurers will meet their legal standard of care under the best contributory negligence rules. In addition, there is a discrete gap between the legal, or customary, standard of care and the care of those injurers who do not meet the standard. Hence, negligent injurers should be easy to identify. Litigation should occur only in the small percentage of accidents where the injurer has not met the legal standard.

On the other hand, in the only examples where we can calculate equilibrium behaviour under best comparative negligence rules, the fraction of injurers supplying care in the 'middle' region, where liability is shared, ranges from 70 per cent to 95 per cent with an average value of 89 per cent. The fraction of victims in the middle region ranges from 40 per cent to 70 per cent, with an average value of 62 per cent. Litigation would be needed to apportion damages in almost all accidents where injurers or victims have taken care in the middle region.

High legal costs are probably the only reason the majority of accidents are not litigated in a comparative negligence regime. In recent research, Low and Smith (1995) examine torts relating to automobile accidents in different states in the United States. They find that, after controlling for other systematic influences, the joint probability of retaining an attorney and filing a lawsuit under a comparative negligence regime was double the probability for a contributory negligence regime.

When individuals are risk averse, it might be thought that the sharing of damages under comparative negligence provides an offsetting benefit. However, comparative negligence is an inefficient method of providing insurance. Danzon (1991:52) reports that the overhead on $\$ 1.00$ of compensation using the tort system has been estimated at 120 per cent as compared with 20 per cent for large group insurance programs. Similarly, Rogers (1994:31) reports that the 1973 (Pearson) Royal Commission on Civil Liability and Personal Injury estimated that the cost of operating the tort system in the UK was 85 per cent of the value of compensation paid through the system, while the corresponding figure for social security (excluding collection costs borne by the employer) was about 11 per cent.

\section{Concluding Remarks}

The simple tort liability rules that the courts settled on after centuries of litigation performed remarkably well in providing individuals with appropriate incentives to take care to avoid accidents. They also tended to discourage unnecessary litigation. Since the rules were simple, they were applied consistently by the courts. The appropriate legal standards of care in different situations became widely known. The legal standard of care for injurers tended to become a customary level of care as almost all injurers had a strong incentive to meet it. Those injurers not meeting the 
standard had an incentive to take distinctly less care. The negligent injurers were then easy to identify, and those injurers taking customary care were protected from unnecessary litigation.

It was a mistake to replace these simple rules by more complicated apportionment rules. Apportionment rules are unlikely to give clear signals about appropriate standards of care. They are also likely to reduce efficiency by encouraging excessive litigation. If it were not for high legal costs, most accidents would result in litigation under a comparative negligence regime.

Recent criticism of the tort law system has focused on the role of contingency fees and the quasi-criminal punitive damages. Our analysis suggests that comparative negligence is a more fundamental source of the difficulties with the current system. In particular, comparative negligence has both reflected and further encouraged the view that the courts should focus on compensation and redistribution at the expense of providing incentives to choose appropriate amounts of care, while at the same time avoiding unnecessary litigation.

\section{References}

Brito, D. \& P. Hartley (1995a), 'Optimality of Negligence Rules when one Class of Agents is Heterogeneous', working paper, Rice University, Houston.

- (1995b), 'Optimality of Negligence Rules when Individuals are Heterogeneous', working paper, Rice University, Houston.

Danzon, P. (1991), 'Liability for Medical Malpractice', Joumal of Economic Perspectives 5: 51-69.

Low, S. \& J. Smith (1995), 'Decisions to Retain Attorneys and File Lawsuits: An Examination of the Comparative Negligence Rule in Accident Law', Journal of Legal Studies 24: 535-57.

Posner, R. (1992), Economic Analysis of Law, Little Brown \& Co., Boston.

Rogers, W. (1994), Winfield and Jolowicz on Tort (14th ed.), Sweet \& Maxwell, London.

Rubinfeld, D. (1987), 'The Efficiency of Comparative Negligence', Journal of Legal Studies 16:375-94.

Trindade, F. \& P. Cane (1985), The Law of Torts in Australia, Oxford University Press, Melbourne.

An earlier version of this article was prepared for a conference on Risk, Regulation and Responsibility sponsored jointly by the Institute for Public Affairs' Regulation Review Unit and The Australian National University's Centre for Applied Economics, and held in Sydney on 13-14 July 1995. 